\title{
ENERGIAADÓ VAGY VALAMI MÁS? A KÖRNYEZETVÉDELMI KÖZTERHEK HATÁSMECHANIZMUSÁRÓL?*
}

\author{
Bartha Ildikó - Nagy Zoltán ${ }^{1}$
}

A gazdasági növekedés egyre nagyobb környezeti terhet ró a Föld ökoszisztémájára, ezért egyre fontosabbá válik a környezetpolitikai szabályozás. Az államnak szabályoznia kell a piaci viszonyokat a környezet védelme érdekében, a kérdés azonban a "hogyan"on van. ${ }^{2}$ A környezetpolitikai szabályozáson belül a gazdasági szabályozó eszközöknek egyre nagyobb jelentőséget tulajdonít a szakirodalom, amelyen belül találhatóak a környezeti adók is. A környezetvédelmi adóbevételek GDP-n belüli arányát, Európa országainak 2011-es adatait összehasonlítva az 1. ábra mutatja.

1. ábra Környezetvédelmi jellegü adóbevételek a GDP százalékában Európa egyes országaiban (2011)

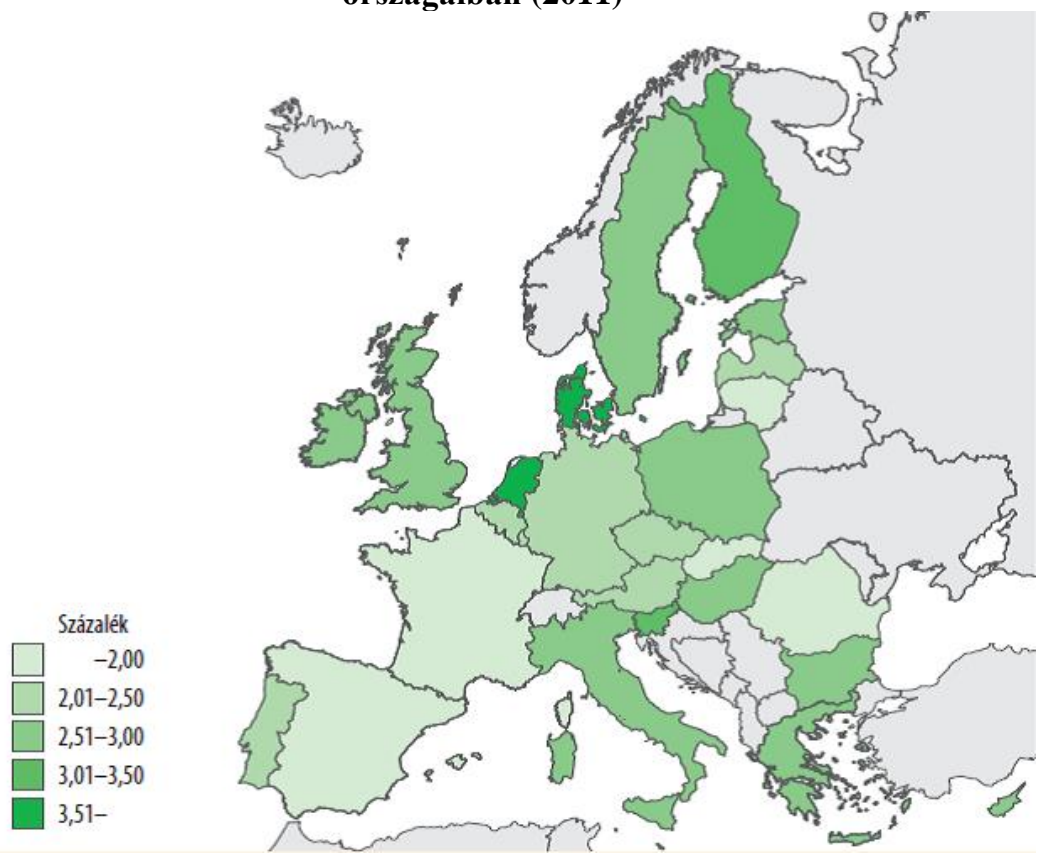

Forrás: Eurostat, KSH

A modern közgazdasági gondolkodás elismeri a piaci viszonyokba való beavatkozást, különösen a környezetvédelmi kérdésekben. A beavatkozás azonban torzítja a piaci

\footnotetext{
${ }^{*}$ DOI 10.21867/KjK/2017.3.2.

${ }^{1}$ Dr. Bartha Ildikó, egyetemi docens, DE ÁJK, tudományos fömunkatárs MTA-DE Közszolgáltatási Kutatócsoport; Dr. habil. Nagy Zoltán, egyetemi docens, ME ÁJK

${ }^{2}$ Az MTA Közjogi Albizottság közelmúltban megrendezett vitaülés tartalmához lásd: Bartha Ildikó Bordás Péter: Ombudsmani est az MTA Közjogi Albizottsággal. KÖZJAVAK, III. évfolyam, 2017/2. szám, 34-35. old.
} 
viszonyokat, ezért olyan eszközök alkalmazására kell, hogy sor kerüljön, amelyeknek legkisebb a torzító hatása, ugyanakkor hatékonyak a környezetpolitikai cél megvalósításában. Természetesen a gazdasági szabályozók sem mindenhatóak, szükség van a hagyományos közvetlen szabályozó eszközökre is. ${ }^{3}$ A környezeti adók kérdésköre viszonylag új terület a hazai jogi szabályozás számára, ezért a kérdéskör több szabályozási problémát felvet. Ilyen kérdés, hogy mely adók tartoznak egyáltalán a környezeti adók közé.

A környezeti adók alatt - széleskörüen értelmezve - nemcsak a hagyományos értelemben vett adókat értjük, hanem a díjakat, járadékokat, vámokat és egyéb közterheket is, azaz minden olyan fizetési kötelezettséget, amelynek környezeti hatása van. Szükebb értelmezésben öko-adók közé csak a közvetlen környezeti közterhek tartoznak. (Például az energiaadók és az egyéb környezetterheléshez kapcsolódó díjak.) Jól látszik tehát, hogy az elmélet sem konzekvens a különböző fogalmak használatában és elsősorban nem pénzügyi jogi, hanem közgazdasági, környezetjogi szemszögböl csoportosítja, tipizálja a rendszert.

2. ábra

\section{Környezeti adók rendszere Magyarországon}

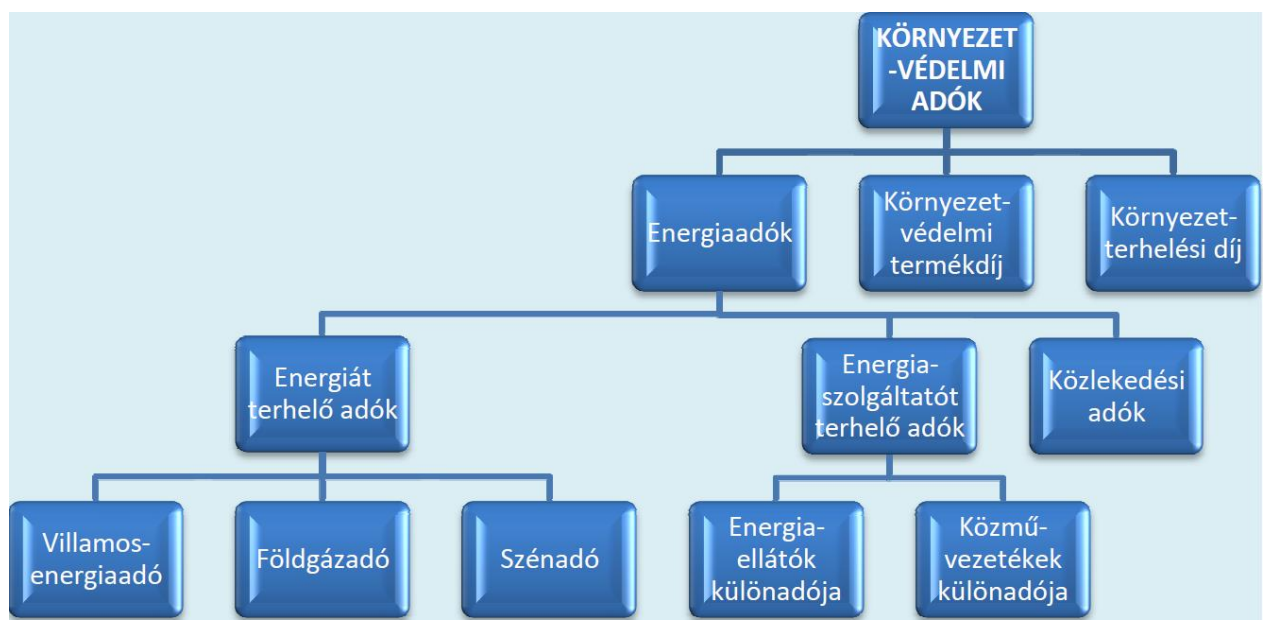

Forrás: saját szerk. Nagy Zoltán: Az adópolitika szabályozási eszközei szolgáltatási szempontból [in: Horváth M. T.- Bartha I. (szerk.) (2016): Közszolgáltatások megszervezése és politikái. Merre tartanak? Budapest, Dialóg-Campus, 219-230. o.] c. tanulmánya alapján

A környezeti adók elméleti megkülönböztetése mellett komoly szakmai vita tárgyát képezi az is, ${ }^{4}$ hogy milyen hatása van a környezeti adóknak, betöltik-e környezetvédelmi szerepüket. A szakirodalmi elemzések több érvet sorakoztatnak fel a környezeti adók előnyei és hátrányai mellett. Ilyen előny a környezeti adók alkalmazásánál a költségtényezők minimalizálása, a statikus ösztönzés és a dinamikus ösztönzés is többek között. A költségtényezők minimalizálásánál hangsúlyozandó, hogy

\footnotetext{
${ }^{3}$ Bartha Ildikó: Nemzetközi szerződések mozgásban: Alkotmányos és nemzetközi jogi kihívások az Európai Unió külkapcsolataiban. Budapest-Pécs, Dialóg Campus Kiadó, 2015, 120.

${ }^{4}$ Don Fullerton-Andrew Leicester-Stephen Smith (2008): Environmental taxes. NBER

Working Paper No. 14197
} 
az adók alkalmasak arra, hogy alacsony költségszinten elérjék az optimális szennyezési szintet. A statikus ösztönzés az adott technológia hatékony kezelését jelenti, hiszen a vállalkozások érdekeltek abban, hogy a hatékony müködtetés révén is csökkentsék a környezetszennyezés mértékét. A dinamikus ösztönzés keretében pedig az adók a vállalkozásokat arra ösztönzik, hogy folyamatosan csökkentsék a káros anyag kibocsátásukat, ezért a kibocsátás a hatóságilag elöírt szint alá is kerülhet.

Mindezen elönyök mellett számos hátránya is van a környezeti adó alkalmazásának. Ilyen hátrány a bizonytalan környezeti hatás, az elosztási hatás többek között. A bizonytalan környezeti hatást az eredményezi, hogy az adók ösztönöznek ugyan, de nem garantálják a szennyezés mértékét. Lehetséges olyan mértékü adóteher, amely mellett a szennyezést vállalják a gazdasági szereplők. Az elosztási hatás szintén nagy problémája a környezeti szabályozásnak. A környezeti adóteher a szállításra, az energiára illetve a környezetet károsító termelö tevékenységre vonatkozik, amely a fogyasztás révén terheli a háztartásokat. Jövedelmi hatás tekintetében az alacsonyabb jövedelmü háztartásokat érinti jelentősebben az adóteher, mivel jövedelmük arányában többet költenek energiára például ezek a háztartások, mint a magasabb jövedelmü társadalmi csoportok.

Hasonlóan több kérdést felvet a jogtudomány számára az adók környezeti hatásmechanizmusa. Ez a kérdés különösen a közszolgáltatások területén merült fel a különadóztatás jelentőségének a növekedésével. Két adónem bemutatásán keresztül jól érzékelhető a környezeti hatás.

Az egyik ilyen közteher a "Robin Hood-adóként" megismert (2013 óta energiaellátók jövedelemadójaként továbbélö) energiaellátók különadója, amelyet a távhőszolgáltatás versenyképesebbé tételéről szóló 2008. évi LXVII. törvény vezetett be. A különadó bevezetésének deklarált célja a távhőszolgáltatás és a vezetékes gázszolgáltatás, illetve az energiafelhasználást csökkentő beruházások támogatása. Ezek az energiaforrások kevésbé környezetszennyezőek, mint más források, ezért az állam támogatja ezek fogyasztását. Alapvetően az adónak csak közvetett környezeti hatása van, mivel az adóból származó források felhasználása révén csökken a károsanyag kibocsátása és az energiafelhasználás mértéke. Közvetlen hatása nincs az energiaszolgáltatásra, mivel nem a fogyasztást adóztatja, tehát nem sarkall energiahatékonyságra, a szennyezőanyag kibocsátás csökkentésére. 2013-tól a jogalkotó jelentősen, csaknem négyszeresére (8\%ról 31\%-ra) emelte az energiaellátók jövedelemadójának a mértékét, ugyanakkor megszüntette az adóból származó bevételek felhasználási kötöttségét. Így, bár nőttek az energiaszektorhoz kapcsolódó adóterhek, csökkent a környezetvédelmi célokra fordítható adóbevételek összege. ${ }^{5}$

A másik, a közmüszolgáltatást jelentősen érintő adónem a közmüvezetékek adója. Az adózás érinti az energiaszolgáltatást, hiszen a földgáz-, hő- és villamosenergiaellátást szolgáló vezetékekre is kiterjed az egyéb víz, szennyvíz, csapadékvíz elvezetését szolgáló és a hírközlési közmüvezetékekre. Milyen hatása lehet az új adónemnek a

\footnotetext{
${ }^{5}$ Nagy Zoltán: Az adópolitika szabályozási eszközei szolgáltatási szempontból in: Horváth M. T.Bartha I. (2016): Közszolgáltatások megszervezése és politikái. Merre tartanak? Budapest, DialógCampus, 229 old.
} 
közmüszolgáltatásra? A szakirodalmi elemzéssel (IDEA, 2012) ${ }^{6}$ egyetértve többféle reakció is modellezhető a szolgáltatók részéről, amelyek kihatással lehetnek a szolgáltatásra. Felmerülhetnek költségcsökkentő intézkedések és a beruházások visszafogása egyaránt, amelyek szolgáltatás színvonalát rontják, amely kihat az energiahatékonyságra és ezen keresztül a környezetre.

Megállapítható tehát, hogy sokféle eszköz áll rendelkezésre a környezetpolitikának a környezetvédelmi érdekek érvényesítésére, de ezek közül a leghatékonyabb, a legkisebb piaci beavatkozással járó kiválasztása célszerü a gazdasági és társadalmi viszonyokra tekintettel. Az eszközök közül ezért van egyre nagyobb jelentősége a környezeti adóztatásnak.

Ahhoz persze, hogy teljes képet alkossunk a fenti adók hatásmechanizmusáról, nem elegendő a környezetpolitikai eszköztár értelmezési tartományában maradnunk. Lévén szó közpénzügyi szabályozó rendszerekről, nem tekinthetünk el az adók és a használati díjak közbevételi szerepétől, nem beszélve a piaci folyamatokra gyakorolt hatásokról, amelyekre már korábban is utaltunk. Az egy-egy kiemelt ágazatra, tevékenységre fókuszáló különadók ${ }^{7}$ kiemelt figyelmet érdemelnek e szempontból. Példájuk - nem csupán a környezetvédelem terén - jól mutatja, hogy az értékpreferencián alapuló állami beavatkozással az egyes (vagy éppen egyedi) piaci szereplők jelentősen szelektálhatóak. Téves lenne tehát azt feltételeznünk, hogy a környezetvédelmi hatásfok a szabályozás egyetlen mozgatórugója minden esetben, és a nem megfelelő eredmény kizárólag a jogalkotói tudatosság hiányának, a jogalkotásban résztvevők szakmai inkompetenciájának tudható be. E kérdések további szakmai vita tárgyát képezheti, amelyre remélhetőleg lesz is alkalom a közeljövőben...

\section{Források jegyzéke:}

- Don Fullerton-Andrew Leicester-Stephen Smith (2008): Environmental taxes. NBER Working Paper No. 14197

- Intézet a Demokratikus Alternatíváért (IDEA)(2012): A különadók reinkarnációja: a közmüadó-kevés központi bevétel-nehezen átháritható teher

- Nagy Zoltán (2016): Az adópolitika szabályozási eszközei szolgáltatási szempontból in: Horváth M. T.- Bartha I. (2016): Közszolgáltatások megszervezése és politikái. Merre tartanak? Budapest, Dialóg-Campus, 219230. old.

- Szlávik János (2005): Fenntartható környezet és eröforrásgazdálkodás, Budapest: KJKKerszöv.

- Bartha Ildikó: Nemzetközi szerződések mozgásban: Alkotmányos és nemzetközi jogi kihívások az Európai Unió külkapcsolataiban. BudapestPécs, Dialóg Campus Kiadó, 2015, 120. old.

\footnotetext{
6 http://docplayer.hu/1136048-A-kulonadok-reinkarnacioja-a-kozmuado-keves-kozponti-bevetelnehezen-atharithato-teher.html (letöltés dátuma: 2017. május 9.)

${ }^{7}$ http://adozona.hu/altalanos/A_legujabb_kulonado_artalmai_KRJH5X (letöltés dátuma: 2017. május 9.)
} 